\title{
ANTS VISIT NECTARIES OF Epidendrum denticulatum (ORCHIDACEAE) IN A BRAZILIAN RAINFOREST: EFFECTS ON HERBIVORY AND POLLINATION
}

\author{
ALMEIDA, A. M. ${ }^{1}$ and FIGUEIREDO, R. A. ${ }^{2}$ \\ ${ }^{1}$ Pós-graduação em Ecologia, Universidade Estadual de Campinas, \\ C.P. 6109, CEP 13083-970, Campinas, SP, Brazil \\ ${ }^{2}$ Coordenação Geral do Centro de Pós-graduação, Faculdades Padre Anchieta de Jundiaí, \\ CEP 13207-660, Jundiaí, SP, Brazil \\ Correspondence to: Adriana Monteiro de Almeida, Departamento de Zoologia, Unicamp, C.P. 6109, \\ CEP 13083-970, Campinas, SP, Brazil, e-mail: adrianam@unicamp.br \\ Received April 8, 2002 - Accepted August 20, 2002 - Distributed November 30, 2003
}

(With 1 figure)

\begin{abstract}
Epidendrum denticulatum (Orchidaceae) produces nectar on the petioles of buds, flowers, and fruits (extrafloral nectaries) but no nectar is found on its flowers, and it is probably a deceptive species. In the Brazilian Atlantic rainforest, some aspects of both the ecology and behavior of Camponotus sericeiventris (Formicinae) and Ectatomma tuberculatum (Ponerinae), two ant species foraging on $E$. denticulatum extrafloral nectaries, were investigated. Both experiments, using termites as baits and field observations, suggest that these ant species are able to prevent reproductive organ herbivory, without affecting pollinator behaviour. Since a low fruit set is often cited as a characteristic of the family, especially for deceptive species, ants attracted to orchid inflorescences protect reproductive structures and increase the probability of pollination success. Epidendrum denticulatum flowers were visited and probably pollinated by Heliconius erato (Nymphalidae) and Euphyes leptosema (Hesperiidae).
\end{abstract}

Key words: ant-plant interaction, foraging behaviour, extrafloral nectaries, pollination ecology.

\section{RESUMO}

Formigas visitam nectáreos de Epidendrum denticulatum (Orchidaceae) em uma área de Mata Atlântica: efeitos sobre herbivoria e polinização

Epidendrum denticulatum (Orchidaceae) produz néctar nos pecíolos de botões florais, flores e frutos (nectáreos extraflorais), mas não em suas flores, e provavelmente "engana" seus polinizadores. Numa área de Mata Atlântica, investigamos alguns aspectos da ecologia e comportamento das formigas Camponotus sericeiventris (Formicinae) e Ectatomma tuberculatum (Ponerinae), ambas encontradas forrageando em nectáreos extraflorais de $E$. denticulatum. Tanto experimentos usando cupins como iscas quanto observações de campo sugerem que ambas as espécies de formiga têm a dupla capacidade de limitar a herbivoria dos órgãos reprodutivos da espécie estudada, sem interferir no comportamento dos polinizadores. Uma vez que baixa taxa de frutificação é característica das orquídeas, principalmente de espécies sem néctar floral, as formigas atraídas para suas inflorescências estão protegendo as estruturas reprodutivas e aumentando a probabilidade de sucesso de polinização. As flores de $E$. denticulatum são visitadas e provavelmente polinizadas por Heliconius erato (Nymphalidae) e Euphyes leptosema (Hesperiidae).

Palavras-chave: interação planta-formiga, comportamento de forrageamento, nectáreos extraflorais, ecologia de polinização. 


\section{INTRODUCTION}

Many tropical plant species produce sugary substances that protect its parts by attracting ants and/or parasitoids. Since some ants tend to be aggressive to other arthropods visiting the plant (Hespenheide, 1985), they reduce herbivory and protect occupied individuals (e.g., Janzen, 1966, 1967; Bentley, 1977a, 1977b; Schemske, 1980; Oliveira et al., 1987; Costa et al., 1992). Many tropical orchids show interactions with ants ranging from those involving myrmecophytic species, in which ants nest (e.g., Rico-Gray, 1989; Fisher $e t$ al., 1990), to those with species on which the ants only frequent to forage on extrafloral nectaries (e.g., Jaffe et al., 1989; Delabie, 1995). Many experiments have shown that ants visiting extrafloral nectaries protect the plant against herbivores. With the exception of Caularthron bilamellatum, the only known orchid to produce nectar at the base of mature leaves (Fisher et al., 1990), all other species with extrafloral nectaries present them on reproductive structures, which suggests that protection of reproductive organs may be important in this group. Although abundant descriptions of orchids with extrafloral nectaries exist, experimental studies testing the protective role of ants in orchids are still scarce (Rico-Gray \& Thien, 1989; Peakall, 1994).

Various authors agree that many orchid species are infrequently visited by pollinators, with a consequent low fruit set (e.g., Calvo, 1993; Neiland \& Wilcock, 1995, 1998). Epidendrum denticulatum Jacq. (Orchidaceae) presents Extrafloral Nectaries (EFNs) on the petioles of its buds, flower, and fruits. During preliminary observations in an area of Atlantic rainforest in Brazil, we observed that Epidendrum denticulatum EFNs were mainly visited by two ant species: Camponotus sericeiventris (GuérinMéneville) (Formicinae) and Ectatomma tuberculatum (Olivier) (Ponerinae). In most cases, inflorescences of $E$. denticulatum without ants had herbivore damage marks, while those with ants did not. Each ant species showed different behaviours while foraging along the reproductive axis. Camponotus sericeiventris showed a dynamic behaviour, walking rapidly through all reproductive parts and changing plants during the day. Ectatomma tuberculatum was less agile than $C$. sericeiventris and usually remained immobile on the base of opened flowers keeping its mandibles opened and pointed upwards.
Since pollination is very infrequent in deceptive orchids and monocotyledons are not able to repair damaged tissues after injury, orchid species would be expected to present some sort of reproductive organ protection. In this study we investigated if the two ant species exploiting $E$. denticulatum $\mathrm{EFNs}$ are effective protectors against herbivores and if they somehow interfere with pollination.

\section{MATERIALS AND METHODS}

\section{Study area}

The study was conducted from July 19 to August 1, 1994, in the Forest Reserve of Companhia Vale do Rio Doce $\left(19^{\circ} 06^{\prime}-19^{\circ} 18^{\prime} \mathrm{S}, 39^{\circ} 45^{\prime}-40^{\circ} 19^{\prime} \mathrm{W}\right.$, 28-65 m), Espírito Santo State, southeastern Brazil. Two areas, with different formations, approximately $17 \mathrm{~km}$ apart, and exposed to sun throughout the day were studied: 1. Flamengo: the edge of a dense forest, with trees reaching $40 \mathrm{~m}$ in height. The area has approximately $1000 \mathrm{~m}^{2}$ and presents sandy soil with Poaceae and some shrubs. 2. Nativo: campo nativo, composed of grasses, shrubs, and treelets arranged in patches, characteristic of Brazilian coastal scrub (restingas). This area represents 6\% of the total area of the reserve (Peixoto \& Gentry, 1990) and comprises a much larger site than the previous one.

\section{Study organisms}

Epidendrum denticulatum Jacq. in both study areas was mostly terrestrial, but some epiphytic individuals were observed up to 2 meters high. Their inflorescence is terminal, and simple or rarely branched. The pink flowers are relatively small (30.2 \pm $3.4 \mathrm{~mm}$ long; $\overline{\mathrm{x}} \pm \mathrm{sd} ; \mathrm{n}=10$, each flower from a different plant) and placed on a terminal raceme. They had no nectar or distinguishable odor. Anthesis occurred in the early morning and additional flowers opened each day (steady-state flowering, sensu Gentry, 1974). From two to six flowers could be observed simultaneously in anthesis. The flowering phenology was not synchroniszed between the two areas and the plants in the Flamengo area ceased flowering during the study, while most plants in the Nativo area were still flowering.

The EFN structures are present on $E$. denticulatum in four different sites within a single reproductive axis: three EFNs are present at each bud, flower, and immature fruit petiole, and one EFN is found at the outer surface of the bracts present in each 
scar bract derived from flower or fruit fall. There are no extrafloral nectaries on leaves of this species. Two ant species were commonly found foraging on $E$. denticulatum EFNs: Camponotus sericeiventris and Ectatomma tuberculatum. Camponotus sericeiventris was only observed on E. denticulatum individuals in Nativo, while E. tuberculatum was present in both areas, but mainly in Flamengo. A Crematogaster species was infrequently observed in some orchid individuals in the Flamengo area.

\section{Ant activities}

In the Nativo area, we recorded data for $96 E$. denticulatum individuals in the reproductive period: number of buds, flowers, fruits, and scar bracts; plant length; and number of $C$. sericeiventris foraging. The number of EFNs on a reproductive axis was estimated by multiplying the number of buds, flowers, and fruits by three, and summing the number of scar bracts. The relation between ant number and that of EFNs was calculated with a Spearman rank correlation coefficient. This analysis was not done for the Flamengo area because no more than one individual of E. tuberculatum in each reproductive axis was ever found. Ant activities were recorded in three sessions of one-hour observations for each ant species for both areas. In each session, a single worker was followed for one hour, and the seconds spent in each activity were registered with a chronometer. Observations were made only on sunny days: July 30 and August 1, from 9:00 to 16:00, in both areas. We identified three basic ant behaviours: 1. Alert: the ant remained immobile with the antennae and front legs lifted from the substrate and pointing forward, and the mandibles held wide open. This behaviour was similar in both species. 2. EFNs feeding: the ant stayed immobile, with its mouthparts in contact with EFNs. 3. Walking: movement over the plant and not foraging on EFNs. Visits to EFNs and alert behaviours were further divided in four classes according to the nectarproducing structure: bud, flower, fruit, or scar bract. The walking behaviour was divided in three: 1. Axis: walking from reproductive to vegetative axis, to leave the individual orchid. 2. Outside: walking outside the original plant. 3. Over petals: walking over the orchid petals.

\section{Field-tests on ant protection}

The behaviour of foraging ants toward potential herbivores was evaluated by using live workers of the termite Nasutitermes sp. as bait (simulated herbivores) for ants on experimental plant pairs, each consisting each of an orchid and the nearest similar sized species (regardless of its family) without EFNs or honeydewproducing homopterans. Live worker termites (Nasutitermes sp.) were glued by the dorsum of the pronotum on the reproductive axis of an orchid with ants and on its pair. We used plastic glue (Cascolar®, Alba Química, Brazil) which is commonly used in this kind of experiment and neither attracts nor repels ants (Oliveira et al., 1987). The experiment was conducted on sunny days on July 29-30, from 9:00 to 11:00 and 13:00 to 15:00. Ninety repetitions were made on plants with $C$. sericeiventris individuals (Nativo), and on 22 plants with E. tuberculatum (Flamengo). The time spent until ant attack was registered with a chronometer, and attack success was considered as when the termite was held by ant mouthparts and lifted from the plant, to be removed. In these experiments only non-epiphytic orchids were used. Differences in mean attack time between species were tested with the Mann-Whitney test.

A similar field-test on plant pairs was performed to test if the ants could interfere in the orchid pollination, by attacking an individual above the flower petals. The termite was gently glued over the flower petal of orchids with ants and over its nearest neighbour for a maximum of five minutes. This experiment was repeated 30 times for different plants with $C$. sericeiventris, and only twice for plants with E. tuberculatum.

\section{Pollinator observation}

Pollinator visits were observed for 52.5 hours (from 6:00 to 18:00) on 20 orchid individuals during a four-week period, summing both areas. Flower visitors were collected to detect pollinia attached to their bodies. In order to determine the pollinia removal rate in the orchid population, for the next two mornings 17 flowers with pollinia in Nativo were marked and inspected for its presence. The fruit set for 89 individuals in Nativo and 20 individuals in Flamengo was calculated as the number of mature or developing fruits divided by the sum of the number of fruits and scar bracts per inflorescence. The fruit set was compared to both areas using the Mann-Whitney test.

\section{RESULTS}

\section{Ants presence and activities}

The ant Ectatomma tuberculatum was the dominant species in Flamengo but very scarce in 
Nativo, while Camponotus sericeiventris was only found foraging on EFNs in Nativo. Even in Nativo, where the two common species were found, we never observed them co-occurring in the same orchid patch.

Camponotus sericeiventris began its activity on the orchid at 7:30, while E. tuberculatum was already on the plant at 6:00. Both species were still visiting EFNs in the orchid until 18:00, when we finished our observations. Ectatomma tuberculatum spent more than two hours foraging on one reproductive axis, while C. sericeiventris was eventually observed changing axes and plants. The ant Camponotus sericeiventris was observed on $49 \%$ of the 116 reproductive plants in Nativo (Table 1), and more ants (max. 3) were found on axes with more EFNs $\left(\mathrm{r}_{\mathrm{s}}=0.303 ; \mathrm{p}<0.005 ; \mathrm{n}=\right.$ 96 ), while we never found more than one individual of E. tuberculatum on each reproductive axis. Ectatomma tuberculatum was found on only $18 \%$ of the orchid individuals in Flamengo.

Camponotus sericeiventris showed more movements per hour $(204,205$, and 223) than did E. tuberculatum $(99,105$, and 122) in three onehour observation sessions. Both ant species visited proportionately more EFNs on fruits and scar bracts (Fig. 1c) and stayed proportionately longer on these structures (Fig. 1d). Although both ant species showed the same three basic behaviours, the proportion of time spent in each differed. Ectatomma tuberculatum was observed in the alert position more often and for longer than C. sericeiventris (Fig. 1a, b) which, however, spent more time walking and foraging on EFNs than did E. tuberculatum (Fig. 1b). Ectatomma tuberculatum movements were slow, while $C$. sericeiventris moved rapidly throughout the plant. Camponotus sericeiventris was also commonly observed changing plants during the day, results suggesting that $C$. sericeiventris was more active and dynamic than E. tuberculatum.

We found four orders of insect herbivores feeding on buds, flowers, and fruits of $E$. denticulatum: two families of Coleoptera (one Chrysomelidae species feeding on flowers, and a Curculionidae species feeding on a fruit), Orthoptera (one Acrididae species feeding on a flower bud), and Hemiptera (one Pentatomidae species feeding on a bud) (Table 1). In the Nativo site we found significantly more herbivores or their marks on plants without $C$. sericeiventris ants $\left(\chi^{2}=56.31 ; \mathrm{df}=1\right.$; $\mathrm{p}<0.001)$, but the same was not true for $E$. tuberculatum in Flamengo $\left(\chi^{2}=1.18 ; \mathrm{df}=1 ; \mathrm{p}>\right.$ 0.05) (Table 1). This result for E. tuberculatum in Flamengo may have been influenced by the small number of ants in this site at the time of the study. All the orchids with ants had no herbivores, but ants were sporadically seen on axes with flowers and buds having herbivore marks (Table 1), which suggests that the other structures in the reproductive axis probably continued to secrete nectar, still attracting ants but to a lesser extent. We found neither herbivores nor their marks on the leaves of Epidendrum denticulatum.

TABLE 1

Number of herbivores found on reproductive structures of $E$. denticulatum in the two studied areas. The cells labelled herbivory contain reproductive structures with herbivore damage marks but without herbivore presence.

\begin{tabular}{|c|c|c|c|c|c|c|c|c|}
\hline \multirow[t]{2}{*}{ Study site } & \multicolumn{6}{|c|}{ Without ants } & \multicolumn{2}{|c|}{ With ants } \\
\hline & 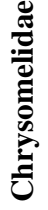 & 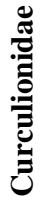 & 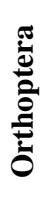 & & 离 & 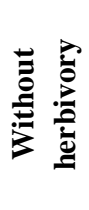 & 离 & $\begin{array}{ll} \\
0\end{array}$ \\
\hline Flamengo & 2 & 0 & 1 & 1 & 1 & 50 & 0 & 12 \\
\hline Nativo* & 2 & 1 & 1 & 5 & 8 & 42 & 2 & 55 \\
\hline
\end{tabular}

* The sum of 116 plants in the Nativo area including some sporadic observations are not included in the statistical tests. 


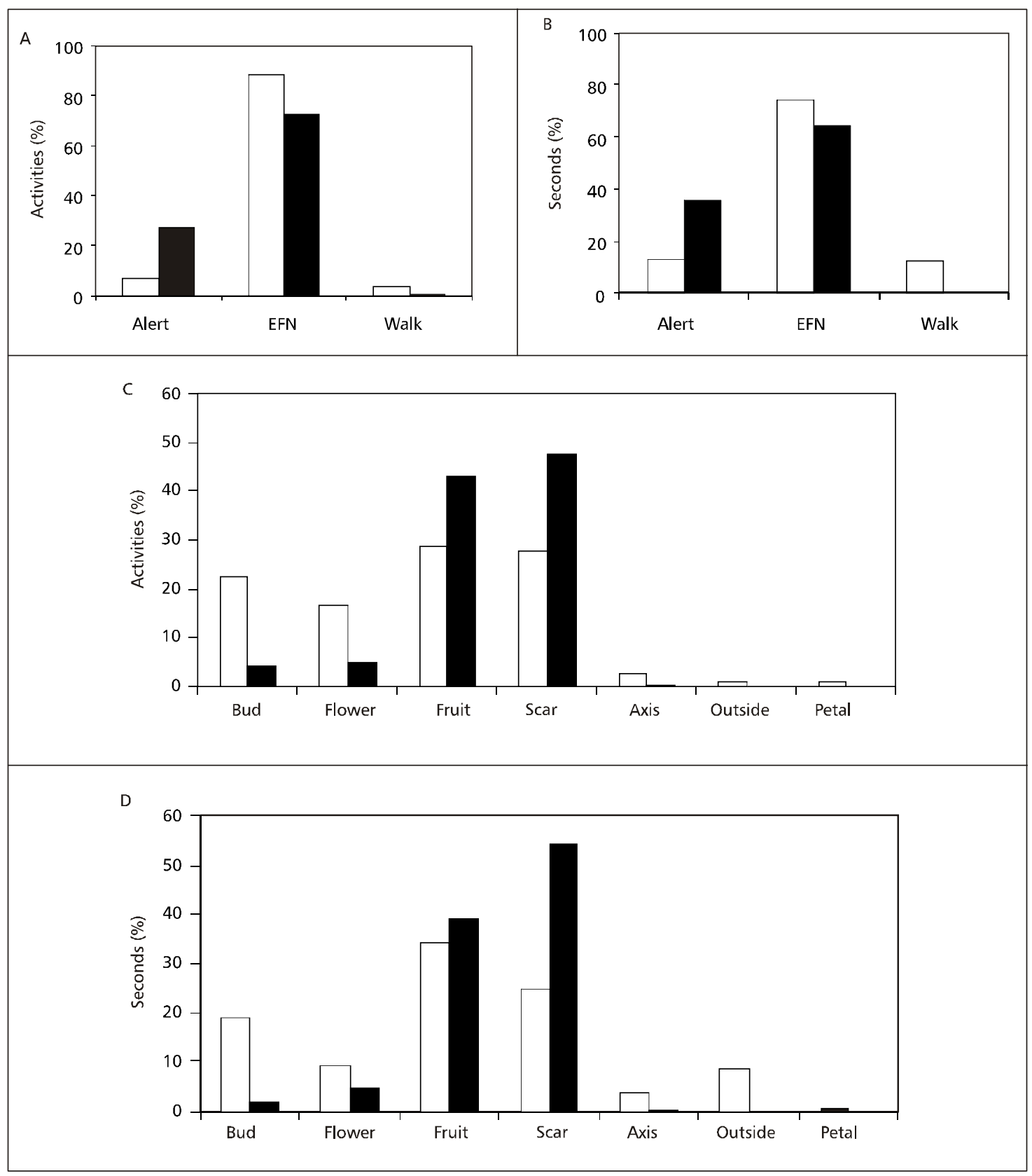

Fig. 1 - Frequency of activities (\%) and time spent (\%) in different behaviours for both ant species found in the EFNs of Epidendrum denticulatum. a. Proportion of activities for the three basic behaviours. b. Proportion of time (in seconds) spent in the three basic behaviours. c. Proportion of activities in different reproductive structures. d. Proportion of time spent (in seconds) in different reproductive structures. $\square$ Camponotus sericeiventris and Ectatomma tuberculatum. 
Camponotus sericeiventris attacked termites glued to the reproductive axis immediately after noticing their presence, and quickly carried them out of the plant. Ectatomma tuberculatum did not attack the bait immediately, but first stopped near the prey and exhibited the alert behaviour, frequently with the abdomen flexed forward between the front legs. (A similar behaviour has been described for the individuals of $E$. tuberculatum that stand in the nest entrance (Dejean \& Lachaud, 1992).) The ant next grasped the termite with its mandibles, inserted its sting, and then carried the termite off the plant. Consequently, Camponotus sericeiventris was considered to attack termites far more rapidly (43.66 \pm 77.12 seconds; $\mathrm{x}+\mathrm{sd}$; $\mathrm{n}=90)$ than did $E$. tuberculatum $(89.89 \pm 82.72$ seconds; $\mathrm{n}=22)(\mathrm{U}=$ $446.500 ; \mathrm{p}<0.001)$. Termites glued to adjacent plants without EFNs or honeydew-producing homopterans were not found by either ant species within 20 minutes.

\section{Pollination}

Orchid flowers were visited by five species of three insect orders: Lepidoptera - Heliconius erato (Nymphalidae, Heliconiinae), Euphyes leptosema (Mabille), and Urbanus sp. (Hesperiidae); one Tabanidae species (Diptera); and one Vespidae species (Hymenoptera). In the Nativo area only one visit by E. leptosema was recorded and no other species visited the flowers. In the Flamengo area each species showed four visits in the observation period, characterizing very low visit frequencies for both areas. In the Flamengo site, E. denticulatum flowers were the only available ones, attracting more unspecialized flower visitors than in the Nativo area. Only 6\% (1 out of 17) of the marked flowers in Nativo had their pollinia removed by the first morning, and $29 \%$ (5 out of 17) had it removed within 48 hours. Pollinia were found only on the mouthparts of te butterflies $H$. erato and $E$. Leptosema. Flower visits of these butterflies lasted less than ten seconds. The fruit set was also very low for both areas and a maximum of six fruits was found in one reproductive axis. The average fruit set in Flamengo $(0.076 \pm 0.156, \mathrm{n}=89)$ was not different from that of Nativo $(0.035 \pm 0.066 ; \mathrm{n}=$ 20) $(\mathrm{U}=1080.000, \mathrm{p}=0.115)$.

Since $C$. sericeiventris contact with the orchid petals was infrequent, this species took much longer to find termites glued to the petals $(370.09 \pm 430.60$ seconds, $\mathrm{n}=32)$ than those glued to the axis $(43.66 \pm 77.12$ seconds; $\mathrm{n}=90)(\mathrm{U}=278.000 ; \mathrm{p}<0.001)$. Termites glued to adjacent plants without EFNs or honeydew-producing homopterans were not found by either ant species within five minutes. In only two observations, E. tuberculatum took respectively 5 and 20 minutes to find a termite glued to the petals.

\section{DISCUSSION}

Various traits present in the family Orchidaceae suggest that there is an investment in protecting reproductive structures. First of all, orchid species particularly are infrequently visited (Neiland \& Wilcock, 1995), and fruit set is very low in this group, especially for deceptive species, which comprise one thirtieth of the family (Neiland \& Wilcock, 1998) in the tropics and temperate areas. A second important trait is that EFNs in Orchidaceae are, with only one known exception (Fisher et al., 1990), restricted to reproductive structures. Peakall (1994) suggests that orchid reproductive structures are "more vulnerable to herbivory, while long-lived leaves could be protected by chemical defences". Moreover, as monocotyledons, orchids have no way to repair damaged tissues if injured by herbivores.

Our results showed that Epidendrum denticulatum in the study area is protected by both ant species foraging on its EFNs. They also show that EFNs of Epidendrum denticulatum are efficient in attracting ants in both studied areas, if compared to adjacent individuals without these structures. Two previous studies confirmed that EFNs in orchids are effective in attracting ants (Jaffe et al., 1989; Delabie, 1995).

Both ant species foraging on EFNs reduced residence time of potential herbivores on $E$. denticulatum reproductive structures. Ectatomma tuberculatum showed fewer movements than $C$. sericeiventris in the same time interval (Fig. 1). Camponotus sericeiventris movements are rapid and they can quickly locate, attack, and withdraw potential herbivores on the orchid, causing a lag in attack time of approximately 40 seconds. This does not mean that one ant species is a better protector against herbivores. Ectatomma tuberculatum also moves throughout the reproductive axis searching for EFNs, and is as effective in attacking simulated baits as is $C$. sericeiventris. Hespenheide (1985) also described Ectatomma ruidum as moving slower 
than Camponotus spp. while foraging on foliar EFNs of Byttneria aculeata, but he found no direct evidence of benefits to plants bearing ants.

Various studies have observed the commonness and great potential for herbivore deterrence of both the genus Camponotus (e.g., Oliveira et al., 1987; Dansa \& Rocha, 1992; Costa et al., 1992; Rico-Gray, 1993), and Ectatomma (Hespenheide, 1985; Jaffe et al., 1989; Rico-Gray, 1989; Dejean \& Lachaud, 1992; Rico-Gray \& Thien, 1989; Peakall; 1994).

We could not detect nectar on the flowers of $E$. denticulatum, and infer that this species is deceptive and pollinators receive no reward at all. From the review from Neiland \& Wilcock (1998), who list three other deceptive tropical Epidendrum species, it seems that this trait is widespread throughout the genus. Neiland \& Wilcock (1998) compared pollination in nectariferous and nectarless orchids in temperate and tropical areas, and found out that in nectariferous species the fruit set is higher. In the present study we found the E. denticulatum average fruit set in both areas to be much lower than that detected by these authors.

We observed Lepidoptera pollinating Epidendrum denticulatum flowers. At least two butterfly species, Heliconius erato and Euphyes leptosema, were seen visiting flowers and taking pollinia. Although we could not confirm the Urbanus species for pollinia presence, Urbanus proteus has already been described as a co-pollinator of Epidendrum secundum (Van der Pijl \& Dodson, 1996). The orchid genus Epidendrum is well known for having psychophilous flowers (pollinated by diurnal Lepidoptera) (Dressler, 1990; Van der Pijl \& Dodson, 1996), and E. denticulatum may not be an exception to the genus.

Experiments showed that ant activities do not seem to interfere with $E$. denticulatum pollination. This was confirmed during one field observation, when a single individual of $H$. erato visited a flower with one $E$. tuberculatum individual in the alert position on the flower petiole. The butterfly arrival was not followed by a response on the part of the ant, immobile which remained. Both ant species are very frequently found on flower petioles, but both experiments and field observations suggest that ants do not show aggressive behaviour towards pollinators, and may not interfere with pollination. As both ant species seldom forage over petals, they may not disturb pollinators, which is confirmed by field observations and by O'Dowd \& Catchpole (1983).

Our results suggest that the presence of ants on $E$. denticulatum may be an efficient protection of the reproductive organs against herbivory. A low rate of pollinator visits and fruit production has already been described for other orchid species (Calvo, 1990, 1993). Epidendrum denticulatum shows a low pollination rate and must invest in the defence of its reproductive organs.

Acknowledgments - This study was carried out as part of the Field Ecology course of the Ecology Program of Campinas State University. The authors would like to thank W. W. Benson and O. H. H. Mielke for butterfly identification, I. R. Leal for ant identification, and E. Borba for orchid identification. The Companhia Vale do Rio Doce and Fundação MB provided logistic support, and CNPq granted financial support. J. Vasconcellos-Neto read and discussed an earlier version of the manuscript. E. L. Borba kindly made improvements in the manuscript.

\section{REFERENCES}

ACKERMAN, J. D., 1986, Mechanisms and evolution of food deceptive pollination systems in orchids. Lindleyana, 1 : 108-113.

BENTLEY, B. L., 1977a, Extra-floral nectaries and protection by pugnacious body guards. Annu. Rev. Ecol. Syst., 8: 407427

BENTLEY, B. L., 1977b, The protective function of ants visiting the extrafloral nectaries of Bixa orellana (Bixaceae). J. Ecol., 65: $27-38$

CALVO, R. N., 1990, Inflorescence size and fruit distribution among individuals in three orchid species. Am. J. Bot., 77: 1378-1381.

CALVO, R. N., 1993, Evolutionary demography of orchids, intensity and frequency of pollination and the cost of fruiting. Ecology, 74: 1033-1042.

COSTA, F. M. C. B., OLIVEIRA-FILHO, A. T. \& OLIVEIRA, P. S., 1992, The role of extrafloral nectaries in Qualea gradiflora (Vochysiaceae) in limiting herbivory, an experiment of ant protection in cerrado vegetation. Ecol. Entomol., 17: 363-365.

DANSA, C. V. A. \& ROCHA, C. F. D., 1992, An ant-membracidplant interaction in a cerrado area of Brazil. J. Trop. Ecol., 8: 339-348.

DEJEAN, A. \& LACHAUD, J. P., 1992, Growth-related changes in predation behaviour in incipient colonies of the ponerine ant Ectatomma tuberculatum (Olivier). Ins. Soc., 39: 129143.

DELABIE, J. H. C., 1995, Formigas associadas aos nectários extraflorais de Epidendrum cinnabarium Salzm. (Orchidaceae) numa área de restinga da Bahia. An. Soc. Entomol. Brasil, 
24: 479-487.

DRESSLER, R. L., 1990, The orchids: natural history and classification. Harvard University Press.

FISHER, B. L., STERNBERG, L. S. L. \& PRICE, D., 1990, Variation in the use of orchid extrafloral nectar by ants. Oecologia, 83: 263-266.

GENTRY, A. H., 1974, Flowering phenology and diversity in tropical Bignoniaceae. Biotropica, 10: 307-309.

HESPENHEIDE, H. A., 1985, Insect visitors to extrafloral nectaries of Byttneria aculeata (Sterculiaceae), relative importance and roles. Ecol. Entomol., 10: 191-204.

JAFFE, K., PAVIS, C., VANSUYT, G. \& KERMARREC, A., 1989, Ants visit extrafloral nectaries of the orchid Spathoglotis plicata Blume. Biotropica, 21: 278-279.

JANZEN, D. H., 1966, Coevolution of mutualism between ants and acacias in Central America. Evolution, 20: 249-275.

JANZEN, D. H., 1967, Interaction of the bull's horn acacia (Acacia cornigera L.) with an ant inhabitant (Pseudomyrmex ferruginea F. Smith) in eastern Mexico. Kans. Univ. Sci. Bull., 47: 315-558.

NEILAND, M. R. M. \& WILCOCK, C. C., 1995, Maximisation of reproductive success by European Orchidaceae under conditions of infrequent pollination. Protoplasma, 187: 3948.

NEILAND, M. R. M. \& WILCOCK, C. C., 1998, Fruit set, nectar reward, and rarity in the Orchidaceae. Am. J. Bot., 85: 16571671.

O’DOWD, D. J. \& CATCHPOLE, E. A., 1983, Ants and extrafloral nectaries, no evidence for plant protection in Helichrysum spp. -ant interactions. Oecologia, 59: 191-
200.

OLIVEIRA, P. S., DA SILVA, A. F. \& MARTINS, A. B., 1987, Ant foraging on extrafloral nectaries of Qualea grandiflora (Vochysiaceae) in cerrado vegetation, ants as potential antiherbivore agents. Oecologia, 74: 228-230.

PEAKALL, R., 1994, Interactions between orchids and ants, pp. 103-134. In: J. Arditti (ed.), Orchid biology: reviews and perspectives, VI. John Wiley \& Sons.

PEIXOTO, A. L. \& GENTRY, A., 1990, Diversidade e composição florística da mata de tabuleiro na Reserva Florestal de Linhares (Espírito Santo, Brasil). Rev. Bras. Bot., 13: 19-25.

RICO-GRAY, V., 1989, The importance of floral and circumfloral nectar to ants inhabiting dry tropical lowlands. Biol. J. Linn. Soc., 38: 173-181.

RICO-GRAY, V., 1993, Use of plant-derived food resources by ants in the dry tropical lowlands of Coastal Veracruz, Mexico. Biotropica, 25: 301-315.

RICO-GRAY, V. \& THIEN, L. B., 1989, Effect of different ant species on the reproductive fitness of Schomburgkia tibicinis (Orchidaceae). Oecologia, 81: 487-489.

SCHEMSKE, D. W., 1980, The evolutionary significance of extrafloral nectar production by Costus woodsonii (Zingiberaceae), an experimental analysis of ant protection. J. Ecol., 68: 959-967.

VAN DER PIJL, L. \& DODSON, C. H., 1996, Orchid flowers: their pollination and evolution. Coral Gables, University of Miami Press. 